\title{
PENGETAHUAN DAN SIKAP KELUARGA PASIEN RAWAT INAP RUMAH SAKIT HAJI SURABAYA TERHADAP PENCEGAHAN INFEKSI NOSOKOMIAL
}

\author{
Nabillah Abubakar*, Neffrety Nilamsari* \\ Departemen Kesehatan dan Keselamatan Kerja \\ *Fakultas Kesehatan Masyarakat Universitas Airlangga \\ Prodi D3 Hiperkes dan Keselamatan Kerja Fakultas Vokasi Universitas Airlangga \\ E-mail : Nabillahabubakar03@gmail.com
}

\begin{abstract}
ABSTRAK
Infeksi nosokomial adalah infeksi yang didapat seorang penderita yang sedang menjalani perawatan rumah sakit. Sumber infeksi nosokomial dapat terjadi pada tindakan non invasif yaitu terjadi kontak antara pasien yang sedang menderita penyakit infeksi menularkan penyakit yang di derita terhadap keluarga pasien. Perantara yang dapat menyebabkan terjadinya infeksi nosokomial di rumah sakit ialah faktor mikroorganisme, faktor pengobatan, faktor lingkungan, faktor tuan rumah.Salah satu faktor penyebab infeksi nosokomial yang menjadi fokus pada penelitian ini adalah infeksi nosokomial yang disebabkan oleh tuan rumah. Tuan rumah dalam penelitian ini adalah keluarga pasien rawat inap Rumah Sakit Haji Surabaya yang kurang sadar dengan personal hygiene. Tujuan penelitian ini adalah untuk mengetahui apakah penyuluhan hand hygiene dapat meningkatkan pengetahuan dan sikap keluarga pasien dalam upaya pencegahan infeksi nosokomial di RS Haji Surabaya. Penelitian ini merupakan penelitian praexperimen dengan rancang bangun one group pretest posttest. Jumlah sampel sebanyak 20 keluarga pasien rawat inap yang diambil secara accidental sampling. Variabel yang diteliti antara lain variabel dependen adalah pencegahan infeksi nosokomial dan variabel independen adalah pengetahuan, sikap, umur, jenis kelamin dan pendidikan. Cara pengambilan data dengan menggunakan kuisioner dan dianalisis dengan menggunakan uji t sampel berpasangan. Hasil penelitian diperoleh adanya perbedaan pengetahuan dan sikap keluarga pasien di RS Haji Surabaya sebelum dan sesudah dilakukan penyuluhan dengan media leaflet.
\end{abstract}

Kata Kunci : Pengetahuan, Sikap, Infeksi Nosokomial

\begin{abstract}
Nosocomial infections are acquired infections a patient who is undergoing hospital treatment. Source of nosocomial infection can occur in non-invasive test that contact occurs between the patients who are suffering from infectious diseases infectious in the suffering of the families of patients. Intermediary which can cause nosocomial infections in hospitals are factors of microorganisms, treatment factor, environmental factor, host factors. One of the cause of nosocomial infections that are the facus of this research is a nosocomial infection caused by the host. Host in this study is the family of inpatient hospital Surabaya Hajj are less aware of personal hygiene. The purpose of this study was to determine whether counseling of hand hygiene can increase the knowledge and attitude of the patient's family in the prevention nosocomial infections in hospitals Haji Surabaya. This research is a design praexperimen with one group pretest posttest. The total sample of 20 families of hospitalized patients were taken by accidental sampling. Variables examined include the dependent variabel is the prevention of nosocomial infections and the independent variables are
\end{abstract}


knowledge, attitude, age, sex and education. How to capture data by using a questionnaire and analyzed using paired samples $t$ test. We observe differences in knowledge and attitudes of families of patients at the Hospital Haji Surabaya before and after counseling with leaflets media.

Keywords : Knowledge, Attitude, Nosocomial Infections

\section{PENDAHULUAN}

Rumah sakit selain untuk mencari kesembuhan juga merupakan sumber dari berbagai penyakit, yang berasal dari penderita maupun dari pengunjung yang berstatus karier. Kuman penyakit ini dapat hidup dan berkembang di lingkungan rumah sakit, seperti udara, air, lantai, makanan dan benda-benda peralatan medis maupun non medis (Anies, 2006). Jadi infeksi yang mengenai seseorang dan infeksi tersebut diakibatkan pengaruh dari lingkungan Rumah sakit disebut infeksi nosokomial. Mengendalikan infeksi yang diakibatkan pengaruh dari lingkungan rumah sakit merupakan salah satu upaya dari safety patient.

Safety patient atau keselamatan pasien merupakan tanggung jawab semua pihak yang berkaitan dengan pemberi pelayanan kesehatan. Keselamatan pasien rumah sakit ada di dalam Panduan Nasional Keselamatan Pasien Rumah sakit Departemen Kesehatan Republik Indonesia tahun 2006. Tujuannya ialah mengidentifikasi resiko keselamatan pasien dan program menekan atau mengurangi kejadian tidak diharapkan.
Salah satu kejadian yang tidak diharapkan ialah infeksi nosokomial. Selain memperparah keadaan pasien, infeksi nosokomial dapat menimbulkan kerugian materi karena pasien akan semakin lama dirawat di rumah sakit.

Infeksi nosokomial (Hospital Acquired Infection/Nosocomial Infection) adalah infeksi yang didapat dari rumah sakit atau ketika penderita dirawat di rumah sakit. Nosokomial berasal dari kata Yunani nosocomium yang berarti rumah sakit. Jadi kata nosokomial artinya "yang berasal dari rumah sakit", sementara kata infeksi artinya terkena hama penyakit. Infeksi ini baru timbul sekurangkurangnya dalam waktu 3 x 24 jam sejak mulai dirawat, dan bukan infeksi kelanjutan perawatan sebelumnya. Rumah sakit merupakan tempat yang memudahkan penularan berbagai penyakit infeksi Ratna et al. (2012).

Faktor penyebab infeksi nosokomial ialah bakteri, virus, jamur dan parasit. Infeksi nosokomial ditentukan oleh virulensi kuman, jumlah kuman, tempat yang rentan terhadap penderita, lamanya kontak dengan penyebab infeksi, dan daya 
tahan tubuh. Adapun perantara yang dapat menyebabkan terjadinya infeksi nosokomial di rumah sakit ialah faktor mikroorganisme, faktor pengobatan, faktor lingkungan, faktor tuan rumah.

Di Indonesia yaitu di 10 RSU pendidikan, infeksi nosokomial cukup tinggi yaitu 6-16\% dengan rata-rata 9,8\% pada tahun 2010. Infeksi nosokomial paling umum terjadi adalah infeksi luka operasi (ILO). Hasil penelitian terdahulu menunjukkan bahwa angka kejadian ILO pada rumah sakit di Indonesia bervariasi antara $2-18 \%$ dari keseluruhan faktor pembedahan (Dharsini, 2010). Pada tahun 2012 angka kejadian nosokomial yaitu $6,64 \% \quad$ (standart $\quad<1,5 \%, \quad$ Kepmenkes (2008)) dan angka kesalahan kelengkapan pengisian rekam medis 24 jam setelah selesai pelayanan yakni $12,75 \%$ (standartnya 100\%, Permenkes (2010)) Wa Satria et al. (2013).

Pada tahun 2015 mulai Januari Desember angka kejadian infeksi nosokomial di Rumah Sakit Haji Sukolilo Surabaya cenderung fluktuatif.

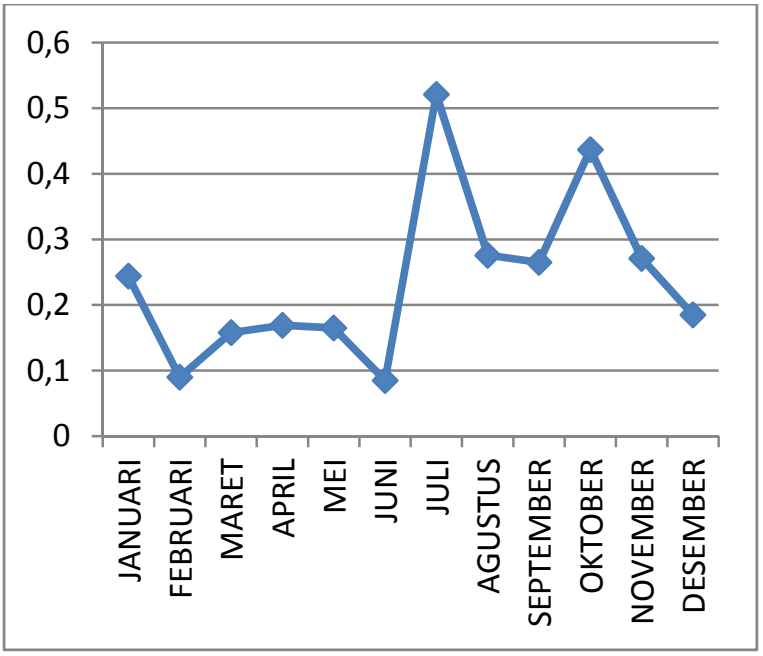

Gambar 1.1 Angka Infeksi Rumah Sakit Tahun 2015

Angka infeksi melonjak tinggi pada 6 bulan terakhir yaitu pada bulan juli sekitar $0.521 \%$ dan bulan Oktober $0.437 \%$. total keseluruhan pasien rawat inap selama tahun 2015 adalah 13669 pasien dan 33 diantaranya terkena infeksi nosokomial. Terjadinya infeksi nosokomial di suatu rumah sakit dapat dipengaruhi oleh mikroorganisme, pengobatan, lingkungan, dan tuan rumah.

Menurut (Septiari, 2012) sumber infeksi nosokomial dapat terjadi pada tindakan non invasif yaitu terjadi kontak langsung antara pasien yang sedang menderita penyakit infeksi dapat menularkan penyakit yang diderita kepada pasien lain, petugas, pengunjung/keluarga, alat-alat rumah sakit, lingkungan rumah sakit dan lain sebagainya.

Di Rumah Sakit Haji Sukolilo Surabaya pada tahun 2016 mempunyai pasien rawat inap sebanyak 903 pada 3 bulan pertama. Angka infeksi nosokomial 
akan semakin berkembang jika pencegahan terhadap infeksi nosokomial tidak dilakukan. Salah satu tahap standart efektif dalam pencegahan dan pengendalian infeksi adalah hand hygiene karena kegagalan dalam menjaga kebersihan tangan adalah penyebab utama infeksi nosokomial dan mengakibatkan penyebaran mikroorganisme multi resisten di fasilitas pelayanan kesehatan.

Mencuci tangan merupakan rutinitas murah dan sangat penting dalam pengontrolan infeksi. Mencuci tangan juga merupakan metode yang paling baik untuk mencegah transmisi mikroorganisme. Telah terbukti bahwa tindakan mencuci tangan secara signifikan menurunkan infeksi pada ICU (Baker, et al., 2008). Menurut penelitian Saragih dan Rumapea (2012) perilaku yang didasarkan pengetahuan akan lebih langgeng daripada perilaku yang tidak didasari dengan oleh pengetahuan. Sehingga pada keadaan ini, tenaga kesehatan yang mempunyai tingkat pengetahuan yang baik tentang cuci tangan menunjukkan kepatuhan melakukan cuci tangan di rumah sakit. Dari 74 responden yang diberikan kuisioner tenaga kesehatan memiliki pengetahuan yang baik mengenai cuci tangan di Rumah Sakit sebanyak 54 orang $(73,0 \%)$ dan tenaga kesehatan yang memiliki pengetahuan kurang sebanyak 20 orang $(27,0 \%)$.
Rumah sakit Haji Sukolilo Surabaya merupakan rumah sakit umum bertipe $\mathrm{B}$ yang mempunyai luas tanah $24000 \mathrm{~m}^{2}$ dan luas bangunan $29294 \mathrm{~m}^{2}$. Mempunyai tempat tidur sebanyak 299 dengan berbagai tipe ruangan. Angka infeksi nosokomial di Rumah Sakit Haji Surabaya masih dibawah $>1.5 \%$ menurut Kepmenkes 2008 angka tersebut masih dalam kategori aman. Tetapi sesuai ketentuan menteri kesehatan angka infeksi nosokomial sebaiknya mendekati angka $0,1 \%$ agar mudah dikendalikan.

Salah satu faktor penyebab infeksi nosokomial adalah kurangnya kesadaran personal hygiene keluarga pasien di RS Haji Sukolilo Surabaya. Berdasarkan penelitian yang sudah ada, pada umumnya meneliti infeksi nosokomial pada pasien dan perawat. Pada penelitian ini peneliti tertarik untuk melakukan penelitian tentang nosokomial di RS Haji Sukolilo Surabaya dengan subyek penelitian keluarga pasien di rawat inap RS Haji Sukolilo Surabaya.

\section{METODE}

Penelitian ini merupakan penelitian praexperimen dengan rancang bangun one group pretest posttest yaitu dilakukan obsevasi pertama (pretest) yang memungkinkan menguji perubahanperubahan yang terjadi setelah adanya experimen. 
Populasi penelitian adalah semua keluarga pasien di rawat inap $\mathrm{RS}$ aji Surabaya. Sampel dlam penelitian ini adalah semua keluarga pasien rawat inap yang berisiko dan berpotensi sebagai agent infeksi nosokomial di RS Haji Surabaya. Besar sampel sebanyak 20 keluarga pasien dan cara pengambilan sampel menggunakan teknik accidental sampling yaitu pengambilan sampel secara sengaja, atau siapa saja yang kebetulan bertemu dengan peneliti dan cocok sebagai sumber data.

1) Kriteria Inklusi

a) Bersedia berpartisipasi dalam penelitian

b) Merupakan keluarga pasien rawat inap Rumah Sakit Haji Sukolilo Surabaya

c) Dapat diajak berkomunikasi

d) Kriteria sampel yang diambil diantaranya berumur $18-60$ tahun

e) Masih berada di ruang rawat inap RS Haji Surabaya sampai 3 hari kedepan

2) Kriteria Ekslusi

a) Berada di ruang ICU selama pengumpulan data

b) Rencana pulang ke rumah dalam 12 hari

c) Berdomisili diluar Surabaya, gresik, dan Sidoarjo
Variabel yang diteliti antara lain vaiabel dependen adalah pencegahan infeksi nosokomial dan variabel independen adalah pengetahuan, sikap, umur, jenis kelamin dan pendidikan. Cara pengambilan data dengan menggunakan kuisioner. Kuisioner untuk variabel pengetahuan diukur dengan menggunakan daftar pertanyaan multiple choice dengan masing-masing pertanyaan memiliki 1 jawaban benar dari 3 pilihan jawaban yang tersedia. Untuk setiap jawaban benar akan mendapat skor 1 dan untuk jawaban salah mendapat skor 0 . Hasil dari kuisioner tersebut selanjutnya dimasukkan dalam kategori menurut Sudjana (2002) yaitu nilai tertinggi yang diperoleh 10 dan terendah mendapat nilai 0. Skala ukur yang digunakan dalam variabel ini adalah skala interval, dimana nilainya diukur dengan menggunakan rumus statistik menurut Sudjana (2002)

$\mathrm{P}=$ Rentang Kelas

$\overline{\text { Banyak Kelas }}$

Dimana P merupakan panjang kelas dengan rentang kelas sebesar 10 (selisih nilai tertinggi dan nilai terendah) dan banyak kelas sebanyak 3 kelas (tinggi, sedang, rendah), maka didapatkan panjang kelas sebesar 3. Dengan menggunakan $\mathrm{P}=$ 
3, maka diperoleh interval sikap nosokomial adalah sebagai berikut:

Tinggi $=7-10$

Sedang $=4-6$

Rendah $=0-3$

Untuk variabel sikap diukur dengan menggunakan skala likert. Diamana pengolahanya menggunakan skoring menurut Sudjana (2002) yaitu dengan pilihan jawaban sangat setuju (SS), setuju (S), tidak setuju (TS), sangat tidak setuju (STS), kuisioner terdiri dari pertanyaan positif dan negatif. Bila pertanyaan positif terdiri dari jawaban sangat setuju diberi nilai 4, setuju diberi nilai 3 , tidak setuju diberi nilai 2 , sangat tidak setuju diberi nilai 1 , sebaliknya untuk pertanyaan negatif jawaban sangat setuju diberi nilai 1 , setuju diberi nilai 2 , tidak setuju diberi nilai 3, sangat tidak setuju diberi nilai 4. Nilai tertinggi yang diperoleh adalah 40 dan nilai terendah sebesar 10. Skala ukur yang digunakan dalam variabel ini adalah skala interval, dimana nilainya diukur dengan menggunakan rumus statistik menurut Sudjana (2002)

$\mathrm{P}=$ Rentang Kelas

$\overline{\text { Banyak Kelas }}$

Dimana $\mathrm{P}$ merupakan panjang kelas dengan rentang kelas sebesar 30 (selisih nilai tertinggi dan nilai terendah) dan banyak kelas sebanyak 3 kelas (tinggi, sedang, rendah), maka didapatkan panjang kelas sebesar 10. Dengan menggunakan $\mathrm{P}$ $=10$, maka diperoleh interval sikap nosokomial adalah sebagai berikut:

Tinggi $=30-40$

Sedang $=20-29$

Rendah $=10-19$

Untuk variabel tindakan kuisioner berbentuk pilihan dikotomus dengan jenis pertanyaan (ya) dan (tidak). Setiap kategori pertanyaan dengan jawaban (ya) diberi skor 1 dan jawaban (tidak) diberi skor 0 (nol). Nilai tertinggi yang diperoleh 10 dan nilai terendah 0 . Skala ukur yang digunakan dalam variable ini adalah skala interval, dimana nilainya dengan menggunakan rumus statistik menurut Sudjana (2002).

$\mathrm{P}=$ Rentang Kelas

$\overline{\text { Banyak Kelas }}$

Dimana $\mathrm{P}=$ panjang kelas dengan rentang sebesar 10 (selisih nilai tertinggi dan nilai terendah) dan banyak kelas sebanyak 3 kelas (tinggi, sedang, kurang) didapatkan panjang kelas sebesar 3. Dengan menggunakan $\mathrm{P}=3$ maka didapatkan nilai interval tindakan pasien/pengunjung dalam pencegahan infeksi nosokomial adalah sebagai berikut:

Tinggi $=7-10$

Sedang $=4-6$

Rendah $=0-3$

Data yang diperoleh dan dikumpulkan dalam penelitian ini adalah data primer dan sekunder. 
a. Data primer

Data primer yaitu data langsung yang diperoleh peneliti dari lapangan tempat penelitian. Dalam hal ini data primer yang diperoleh adalah data tentang infeksi pengetahuan, sikap, dan tindakan keluarga pasien rawat inap. Karakteristik keluarga pasien seperti umur, jenis kelamin, dan pendidikan.

b. Data sekunder

Data sekunder yang peneliti dapatkan terdiri dari data tentang sejarah rumah sakit, visi dan misi rumah sakit, struktur organisasi rumah sakit. Data infeksi nosokomial yang terdiri dari sumber bahaya infeksi nosokomial, pencegahan infeksi nosokomial yang dilakukan oleh Rumah Sakit Haji Surabaya dalam pengendalian infeksi nosokomial.

Data yang telah diperoleh dan terkumpul akan dilakukan pengolahan secara tabulasi dan tekstular. Analisis data dilakukan pada data pengetahuan, sikap, dan tindakan responden untuk mengetahui apakah ada perbedaan pengetahuan, sikap, dan tindakan sesudah dan sebelum diberikan leaflet dan penyuluhan dengan menggunakan uji t sampel berpasangan. Hasil dari analisis dengan menggunakan uji $\mathrm{t}$ sampel berpasangan ini akan menunjukkan apakah leaflet dan penyuluhan dapat dijadikan sebagai solusi alternatif dalam upaya peningkatan pengetahuan, sikap dan tindakan terhadap pengendalian infeksi nosokomial di rumah sakit.

\section{HASIL}

Hasil penelitian meliputi karakteristik keluarga pasien rawat inap RS Haji Surabaya dan analisis perbedaan pengetahuan dan sikap keluarga pasien rawat inap RS Haji Surabaya tahun 2016 sebelum dan sesudah diberikan penyuluhan kesehatan.

Tabel 5.1 Distribusi umur keluarga pasien rawat inap Rumah Sakit Haji Sukolilo Surabaya tahun 2016

\begin{tabular}{ccc}
\hline $\begin{array}{c}\text { Umur } \\
\text { Keluarga } \\
\text { Pasien } \\
\text { (tahun) }\end{array}$ & $\begin{array}{c}\text { Jumlah } \\
\text { (N) }\end{array}$ & $\begin{array}{c}\text { Persentase } \\
(\%)\end{array}$ \\
\hline $18-32$ & 5 & 25 \\
$33-46$ & 9 & 45 \\
$47-60$ & 6 & 30 \\
\hline Total & 20 & 100 \\
\hline
\end{tabular}

Pada tabel di atas dapat dijelaskan bahwa sebagian besar keluarga pasien di Rawat Inap Rumah Sakit Haji Sukolilo Surabaya berumur antara 33-46 tahun sebesar 45\% dan sebagian kecil keluarga pasien berada di rentang umur 18-32 tahun sebesar 25\%. 
Tabel 5.2 Distribusi jenis kelamin keluarga pasien rawat inap Rumah Sakit Haji Sukolilo Surabaya tahun 2016

\begin{tabular}{ccc}
\hline $\begin{array}{c}\text { Jenis } \\
\text { Kelamin } \\
\text { Keluarga } \\
\text { Pasien }\end{array}$ & $\begin{array}{c}\text { Jumlah } \\
\text { (N) }\end{array}$ & $\begin{array}{c}\text { Persentase } \\
(\mathbf{\%})\end{array}$ \\
\hline Perempuan & 9 & \\
Laki-laki & 11 & 55 \\
\hline Total & 20 & 100 \\
\hline
\end{tabular}

Pada tabel di atas keluarga pasien rawat inap Rumah Sakit Haji Sukolilo Surabaya sebanyak $45 \%$ berjenis kelamin perempuan dan $55 \%$ berjenis kelamin lakilaki.

Tabel 5.3 Distribusi tingkat pendidikan keluarga pasien Rumah Sakit Haji Sukolilo Surabaya tahun 2016

\begin{tabular}{ccc}
\hline $\begin{array}{c}\text { Tingkat } \\
\text { Pendidikan } \\
\text { Keluarga } \\
\text { Pasien }\end{array}$ & $\begin{array}{c}\text { Jumlah } \\
(\mathbf{N})\end{array}$ & $\begin{array}{c}\text { Persentase } \\
(\%)\end{array}$ \\
\hline $\begin{array}{c}\text { SD atau } \\
\text { sederajat }\end{array}$ & 2 & 10 \\
$\begin{array}{c}\text { SMP atau } \\
\text { sederajat }\end{array}$ & 3 & 15 \\
$\begin{array}{c}\text { SMA ata } \\
\text { sederajat } \\
\text { S1 }\end{array}$ & 12 & 60 \\
\hline Total & 3 & 15 \\
\hline
\end{tabular}

Pada tabel di atas menunjukkan sebagian besar keluarga pasien rawat inap Rumah Sakit Haji Sukolilo Surabaya mempunyai tingkat pendidikan SMA atau sederajat sebesar $60 \%$ dan sebagian kecil keluarga pasien adalah tamatan SD sederajat sebesar $10 \%$.

Tabel 5.4 Distribusi tingkat pengetahuan keluarga pasien rawat inap Rumah Sakit Haji Sukolilo Surabaya tahun 2016 sebelum dan sesudah dilakukan penyuluhan

\begin{tabular}{ccccc}
\hline \multirow{2}{*}{ Tingkat } & \multicolumn{4}{c}{ Penyuluhan } \\
\cline { 2 - 5 } pengetahuan & Sebelum & \multicolumn{3}{c}{ Sesudah } \\
\cline { 2 - 5 } & $\mathbf{N}$ & $\mathbf{\%}$ & $\mathbf{N}$ & $\mathbf{\%}$ \\
\hline Baik & 8 & 40 & 18 & 90 \\
Cukup & 7 & 35 & 2 & 10 \\
Rendah & 5 & 25 & 0 & 0 \\
\hline Total & 20 & 100 & 20 & 100 \\
\hline
\end{tabular}

Pada tabel diatas keluarga pasien rawat inap Rumah sakit Haji Sukolilo Surabaya sebelum mendapatkan penyuluhan memiliki pengetahuan baik sebesar $40 \%$, memiliki pengetahuan cukup sebesar $35 \%$, dan memiliki pengetahuan rendah sebesar $25 \%$. Sesudah diberikan penyuluhan oleh peneliti yang memiliki pengetahuan kurang turun dari $25 \%$ menjadi $0 \%$, yang memiliki pengetahuan cukup turun dari $35 \%$ menjadi $10 \%$, dan yang memiliki pengetauan baik naik dari $40 \%$ menjadi $90 \%$. Hal ini berarti terjadi perubahan pada setiap kategori, yaitu pada kategori naik 50\%, pada kategori cukup turun 25\%, dan kategori rendah turun $25 \%$. 
Tabel 5.5 Distribusi sikap keluarga pasien rawat inap Rumah Sakit Haji Sukolilo Surabaya tahun 2016 sebelum dan sesudah dilakukan penyuluhan

\begin{tabular}{ccccc}
\hline Sikap & \multicolumn{4}{c}{ Penyuluhan } \\
\cline { 2 - 5 } & \multicolumn{3}{c}{ Sebelum } & \multicolumn{3}{c}{ Sesudah } \\
\cline { 2 - 5 } & $\mathbf{N}$ & $\mathbf{\%}$ & $\mathbf{N}$ & $\%$ \\
\hline Baik & 5 & 25 & 20 & 100 \\
Cukup & 15 & 75 & 0 & 0 \\
Kurang & 0 & 0 & 0 & 0 \\
\hline Total & 20 & 100 & 20 & 100 \\
\hline
\end{tabular}

Berdasarkan tabel di atas tidak ada sikap keluarga pasien yang kurang mendukung upaya pencegahan infeksi nosokomial di rumah sakit khususnya di ruang rawat inap. Keluarga pasien mempunyai sikap baik dan sangat mendukung upaya pencegahan infeksi nosokomial sebesar 25\% dan mempunyai sikap cukup dalam mendukung upaya pencegahan infeksi nosokomial sebesar $\quad 75 \%$. Setelah dilaksanakan penyuluhan mengenai infeksi nosokomial sikap keluarga pasien di kategori baik dan sangat mendukung pencegahan infeksi naik dari 25\% menjadi $100 \%$ dan keluarga pasien yang mempunyai sikap cukup turun dari $75 \%$ menjadi $0 \%$.

Hasil analisa menggunakan uji $\mathrm{t}$ beda rerata masing - masing total skor pengetahuan dan sikap yang di dapat dari keluarga pasien rawat inap Rumah Sakit Haji Sukolilo Surabaya sebelum dan sesudah dilakukan penyuluhan mengenai infeksi nosokomial, menunjukkan nilai $\mathrm{P}=$
0,000 dengan menggunakan $\alpha=0,05$ hal ini berarti bahwa terdapat perbedaan sebelum dan sesudah dilakukan penyuluhan terhadap keluarga pasien rawat inap Rumah Sakit Haji Sukolilo Surabaya.

\section{PEMBAHASAN}

Penyuluhan merupakan salah satu inovasi kegiatan yang diberikan pada keluarga pasien yang terpapar bahaya infeksi dan sekaligus dapat menjadi perantara penularan infeksi tersebut. Tujuan penyuluhan untuk meningkatkan pengetahuan dan sikap keluarga pasien dalam upaya pencegahan infeksi nosokomial di ruang rawat inap Rumah Sakit Haji Sukolilo Surabaya. Keunikan dari kegiatan ini adalah dalam penyampaian materinya karena penyuluhan dilakukan diberikan kepada keluarga pasien secara personal.

Lima elemen dasar dalam proses komunikasi yang disampaikan oleh Harold Lasswell dengan istilah "Who Says What in Which Channel to Whom with What Effect”. Kelima elemen dasar tersebut adalah sumber atau komunikator, pesan, saluran, penerima, efek atau dampak. Berhasil atau tidaknya komunikasi tergantung dari kelima elemen tersebut. Bagaimana komunikator bisa mempengaruhi komunikanya, sehingga bisa bertindak bahkan bisa merubah sikap 
dan perilaku dari komunikan tersebut. Pada penyuluhan tersebut peneliti sebagai komunikator yang menyampaikan pesan mengenai infeksi nosokomial meliputi definisi infeksi nosokomial, cara penularan infeksi nosokomial, faktor penyebab infeksi nosokomial dan cara pencegahan infeksi nosokomial. Penyampaian pesan menggunakan saluran atau media leaflet yang diberikan kepada komunikan (keluarga pasien). Dampak atau efek yang terjadi setelah diberikan penyuluhan adalah perubahan perilaku dan bertambahnya pengetahuan mengenai infeksi nosokomial.

Melalui penerapan metode komunikasi yang efektif maka pesan dapat di dengar dan dimengerti oleh keluarga pasien sehingga membentuk tanggapan positif. Tanggapan positif dari keluarga pasien terlihat pada terjadinya peningkatan pengetahuan dan sikap keluarga pasien dalam upaya pencegahan infeksi nosokomial. Hal ini dibuktikan dalam analisis data kuisioner yang diberikan kepada keluarga pasien sebelum dan sesudah diberikan penyuluhan. Hasil uji t beda rerata menunjukkan $\mathrm{P}=0,000$ yang berarti terdapat perbedaan pengetahuan sebelum dan sesudah diberikan penyuluhan, perubahan ini mengarah ke hal yang positif yang terlihat sebelum dilakukan penyuluhan keluarga pasien dengan pengetahuan tinggi sebesar $40 \%$ dan setelah diberikan penyuluhan naik menjadi 90\%. Hal ini berarti terjadi peningkatan sebesar $50 \%$ untuk pengetahuan tinggi di keluarga pasien. Sikap keluarga pasien sebelum dan sesudah diberi penyuluhan juga berdampak positif, hal ini dibuktikan dengan hasil analisis uji $\mathrm{t}$ beda rerata yang menunjukkan $\mathrm{P}=0,000$ yang berarti terdapat perbedaan sikap keluarga pasien sebelum dan sesudah diberikan penyuluhan. Perbedaan ini mengarah pada kondisi baik dan sikap yang mendukung upaya pencegahan infeksi nosokomial. Hal ini terlihat bahwa sebelum dilakukan penyuluhan, sikap baik dan mendukung upaya pencegahan infeksi nosokomial sebesar $25 \%$ dan setelah dilakukan penyuluhan naik menjadi $100 \%$. Terlihat perbedaan antara sebelum dan sesudah penyuluhan sebesar $75 \%$.

Menurut Soeripto (2008) suatu program penyuluhan merupakan upaya pembentukan sikap selamat dan sikap konstruktif dan menghilangkan prasangka yang merugikan. Melalui penyuluhan infeksi nosokomial diharapkan keluarga pasien mampu menerapkan sikap baik dalam upaya pencegahan infeksi nosokomial di ruang rawat inap Rumah Sakit Haji Sukolilo Surabaya melalui tindakan rutin mencuci tangan. Kegiatan 
mencuci tangan harus secara rutin dilakukan sebelum dan sesudah kontak dengan pasien, sebelum dan sesudah keluar masuk rumah sakit, sebelum dan sesudah dari toilet. Keluarga pasien diharapkan menghilangkan prasangka buruk dari mencuci tangan seperti malas.

Meningkatnya pengetahuan dan sikap keluarga pasien rawat inap Rumah Sakit Haji Sukolilo Surabaya berpotensi terimplementasinya perilaku sehat yang patuh dalam cuci tangan selama menunggu pasien di ruang rawat inap. Menurut Budioro (1998) bentuk operasional perilaku mencakup tiga komponen utama yaitu: Knowledge (pengetahuan), Atittude (sikap), Practice (tindakan). Sehingga apabila pengetahuan dan sikap keluarga pasien mendukung pencegahan infeksi nosokomial maka hal itu akan tercermin dengan tindakan keluarga pasien yang taat dalam melakukan cuci tangan.

Hasil penelitian ini sejalan dengan penelitian Luluq (2014) dengan judul penelitian "Pengaruh Penyuluhan Kesehatan Dengan Media Video Terhadap Pengetahuan dan Sikap Personal Hygiene Siswa SD Negeri 1 Klepek Kulon Progo" yang menjunjukkan bahwa sebagian besar responden pada kelompok experimen setelah dilakukan penyuluhan memiliki tingkat pengetahuan pada kategori baik yaitu sebanyak 32 responden (89.97\%) sedangkan sebagian besar responden pada kelompok experimen setelah dilakukan penyuluhan memiliki sikap pada kategori baik sebesar 34 responden (94.4\%). Hal ini dikarenakan adanya informasi yang masuk melalui penyuluhan sehingga mempengaruhi pengetahuan dan sikap siswa. Dibandingkan dengan siswa yang tidak diberi penyuluhan tidak ada peningkatan yang signifikan karena tidak ada informasi yang masuk.

\section{SIMPULAN DAN SARAN}

Simpulan:

Keluarga pasien di ruang rawat inap Rumah Sakit Haji Sukolilo Surabaya sebagian besar berusia 33 - 46 tahun (45\%), dan sebagian besar keluarga pasien rawat inap Rumah Sakit Haji Sukolilo Surabaya mempunyai tingkat pendidikan terakhir SMA atau sederajat $(60 \%)$.

Sebelum dilakukan penyuluhan sebagian besar pengetahuan keluarga pasien di rawat inap Rumah Sakit Haji Sukolilo Surabaya adalah baik sebesar $40 \%$, sikap yang cukup mendukung sebesar $75 \%$, dan tindakan baik sebesar $60 \%$. Setelah dilaksanakan penyuluhan tingkat pengetahuan baik naik sampai $50 \%$ dari sebelumnya, sikap yang cukup mendukung turun sampai $75 \%$, dan tindakan baik naik sampai 35\%. 
Berdasarkan uji statistik uji t test beda rerata pada pengetahuan dan sikap $\mathrm{P}=$ 0,000 dan tindakan $\mathrm{P}=0,016$ yang artinya terdapat perbedaan yang bermakna sebelum dan sesudah dilakukan penyuluhan.

Saran :

Pengendalian secara administratif yang sangat memungkinkan untuk dilakukan adalah pembatasan jam berkunjung keluarga yang lebih diperketat oleh pihak rumah sakit.

Memberikan punishment terhadap keluarga pasien yang melanggar peraturan rumah sakit dalam upaya pencegahan infeksi nosokomial.

Agar keluarga pasien tetap konsisten berpartisipasi dalam pencegahan infeksi nosokomial, sebaiknya setiap ada keluarga pasien baru yang akan merawat pasien perawat rumah sakit haji dapat memberikan sedikit briefing kepada keluarga pasien secara singkat, padat dan jelas.

Penyuluhan dapat dijadikan sebagai solusi alternatif untuk meningkatkan pengetahuan, sikap, tindakan keluarga pasien rawat inap Rumah Sakit Haji Sukolilo Surabaya dalam pencegahan infeksi nosokomial oleh karena terdapat perbedaan sebelum dan setelah dilaksanakan penyuluhan.

\section{DAFTAR PUSTAKA}

Almahdor, Nabillah abubakar, 2016, Upaya Pengendalian Infeksi Nosokomial di Rumah Sakit Haji Sukolilo Surabaya dengan Hand Hygiene 2016, skripsi, Surabaya, FKM Universitas Airlangga.

Darmadi. 2008. Infeksi Nosokomial: Problematika dan Pengendalianya. Jakarta: Salemba Medika.

Departemen Kesehatan R.I (2006). Panduan Nasional Keselamatan Pasien Rumah Sakit. Jakarta: Bhakti Husada.

Ducel, G. et al. 2002. Prevention of hospital - acquired infection, A practical Guiede. $2^{\text {nd }}$ edition. World Health Organization. Departement Of Communicable disease, Surveillance and respone.

Mardan Ginting, 2001, Infeksi Nosokomial dan Manfaat Pelatihan Keterampilan Perawat terhadap Pengendalianya di Ruang Rawat Inap Penyakit Dalam RSUP $\mathrm{H}$. Adam Malik Medan Tahun 2001, skripsi, Medan, Poltekes Medan.

Ika, L.A., 2010. Pengetahuan, Sikap, dan Tindakan Keluarga Pasien Tentang Pencegahan Infeksi Nosokomial Pada Ruang Kelas III Instalasi rawat Inap Terpadu A dan Rawat Inap Terpadu B Rumah Sakit Umum Pusat Haji Adam Malik Tahun 2010, skripsi, Universitas Sumatera Utara.

Kadek, H.R., Sang, K.A, 2014. Hubungan Tingkat Pengetahuan Dengan Perilaku Mencuci Tangan Petugas Kesehatan di Rumah Sakit Umum Daerah Badung Tahun 2013. Community Health 2014, Vol II/No.1: 21-31. 
Keputusan Menteri Kesehtan, 2010, Standar Kesehatan dan Keselamatan Kerja di Rumah Sakit Nomor:1087/MENKES/SK/VIII/20 10. Jakarta: Departemen Kesehatan

Linda, T., Debora, B., N.McIntosh, 2004. Paduan Pencegahan Infeksi Untuk Fasilitas Pelayanan Kesehatan dengan Sumber Daya Terbatas, Edisi Kedua, Yayasan Bina Pustaka Sarwono Prawirohardjo. Jakarta.

Luluq, E, 2014. Pengaruh Penyuluhan Kesehatan Dengan Media Video Terhadap Pengetahuan dan Sikap Personal Hygiene Siswa SD Negeri 1 Kepek Pengasih Kulon Progo. Skripsi, Yogyakarta, Sekolah Tinggi Ilmu Kesehatan Aisyiyah

Menteri Kesehatan Republik Indonesia, 2010, Peraturan Menteri Kesehatan Nomor : 340/Menkes/PER/III/2010 tentang Klasifikasi Rumah Sakit. Jakarta: Departemen Kesehatan.

Notoatmodjo, S., 2003. Pendidikan dan Perilaku Kesehatan. Jakarta: P.T.Rineka Cipta.

Parhusip, $\quad$ Faktor-faktor yang mempengaruhi Terjadinya Infeksi Nosokomial serta Pengendalianya di BHG. UPF. Paru RS. DR.Pirngadi/Lab. Penyakit Paru FK-USU Medan, Universitas Sumatera Utara.

Ramli, S., 2010. Pedoman Praktis Manajemen Risiko dalam Perspektif K3 OHS Risk Management. Jakarta: Dian Rakyat.

Ratna, N., Suhartono, dan Sri W, 2012. Infeksi Nosokomial di RSUD Setjonegoro Kabupaten Wonosobo. Media Kesehatan Masyarakat Indonesia, Vol.11/No.1, 94-100.
Rusdiana Kasuarina, 2006, Implementasi Fungsi-fungsi Manajemen Pengendalian Infeksi Nosocomial di Rumah Sakit Roemani Muhammadiyah Semarang, FKM UNDIP.

Sari, L.A., 2010. Hubungan Pengetahuan Sikap Terhadap Penerapan PrinsipPrinsip Pencegahan Infeksi Nosokomial (Universal Precaution)pada perawat di Rumah Sakit Umum Haji Surabaya. Skripsi. Surabaya, Universitas Airlangga: 53.

Saragih, Rumapea. 2012. Hubungan Karakteristik Perawat Dengan Tingkat Kepatuhan Perawat Melakukan Cuci Tangan di Rumah Sakit Columbia Asia Medan. Fakultas Ilmu Keperawatan. Available.http:/ /uda.ac.id/jurnal/files/7.pdf.

Septiari, B.B., 2012. Infeksi Nosokomial. Yogyakarta: Nuha Medika.

Soeripto, M, 2008. Higiene Industri. Jakarta: Balai Penerbit FKUI.

Sudjana, 2002. Metode Statistika. Edisi 6, Bandung: Tarsinto

Taufik, M., 2010. Asal Usul Pengetahuan dan Hakekat Pengetahuan Berbagai Aliran Sekitar Hakekat Pengetahuan dan Sumber-Sumber Pengetahuan. Institue Pertanian Bogor Program Pasca Sarjana Manajemen dan Bisnis.

Wahyu, E., 2011. Penerapan Metode Balanced Scorecard Sebagai Tolok Ukur Penilaian Kinerja Pada Organisasi Nirlaba di Rumah Sakit Bhayangkara Semarang. Skripsi. Semarang, Universitas Diponegoro 